\title{
Effects of copper and zinc on chondrocyte behaviour and matrix turnover
}

\author{
M. E. Davies', M. Pasqualicchio², F. Henson ${ }^{3}$ and G. Hernandez-Vidal' \\ 1 Strangeways Research Laboratory, Cambridge, UK. \\ 2 Istituto di Farmacologia, Universita di Verona, Italy. \\ 3 University of Cambridge, Department of Clinical Veterinary Medicine, Cambridge, UK.
}

\begin{abstract}
Summary
The effects of copper and zinc on proteoglycan (PG) metabolism by articular cartilage were investigated in vitro using normal pig and horse cartilage co-cultured with synovial tissue. PG synthesis was measured by ${ }^{35} \mathrm{SO}_{4}$ incorporation and PG depletion was assessed by toluidine blue staining. Copper, but not zinc, had a slight stimulatory effect on PG synthesis in normal cartilage and was able to reverse the depletion of $P G$ induced by synovial tissue in a dose-dependent manner. Chondrocytes in co-cultured cartilage expressed elevated levels of the PG-degrading enzymes cathepsins $B$ and $D$, as detected by immunocytochemistry. Copper $(0.01 \mathrm{mM})$ reduced expression of these enzymes.
\end{abstract}

Key words: $\quad$ proteoglycan, cartilage, cathepsin B, cathepsin D, copper, zinc

\begin{abstract}
Wirkungen von Kupfer und Zink auf das Verhalten der Chondrozyten und den Stoffwechsel der Matrix
Der Effekt von Kupfer und Zink auf den Proteoglycan (PG) Metabolismus von Gelenkknorpeln wurde in gemischten Kulturen von normalem Schweine- und Pferdeknorpel und Synovialgewebe in vitro untersucht. Die PG-Synthese wurde durch ${ }^{55} \mathrm{SO}_{4}$-Einbau gemessen und die PG-Abnahme wurde durch Toluidin-Blau-Färbung abgeschätzt. Kupfer, nicht aber Zink, hatte einen geringfügig stimmulierenden Effekt auf die PGSynthese in normalem Knorpel und war abhängig von der Dosis in der Lage, den PG-Abbau durch Synovialgewebe umzukehren. Chondrozyten zeigten wie durch Immunocytochemie nachgewiesen, in gemischten Knorpelgewebekulturen erhöhte Konzentrationen der PG-abbauenden Enzyme Kathepsin B und D. Kupfer (0.01 mM) reduzierte das Auftreten von diesen Enzymen.
\end{abstract}

Schlüsselwörter: Proteoglycan, Knorpel, Kathepsin B, Kathepsin D, Kupfer, Zink

\section{Introduction}

Clinical evidence points towards an increase in young horses of bone formation defects in the form of developmental orthopaedic diseases (DOD) such as dyschondroplasia (osteochondrosis), osteochondritis dissecans, Wobble syndrome (cervical spondylomyelopathy) and some angular limb deformities (Knight et al. 1990). These diseases are generally characterized by lesions in the cartilaginous growth centres resulting in defective cartilage and bone growth (Bridges \& Harris 1988; Knight et al. 1990; Meyer 1994), and it is now recognized that a relationship exists between the cartilage and bone defects seen in DOD and nutritional copper and zinc imbalance (Bridges et al. 1984; Cymbaluk \& Smart 1993; Meyer 1994).

Copper and zinc are known to affect cartilage matrix remodelling (Bridges \& Moffitt 1990; Knight et al. 1990; Hurtig et al. 1993) and there is recent evidence to suggest that copper deficiency results in defective collagen cross-linking in cartilage lesions in osteochondrotic foals (Hurtig et al. 1993). The other major structural component of the matrix is proteoglycan, which exists as large macromolecular aggregates, non-covalently bound to hyaluronic acid. It has been reported that copper deficiency in rats alters the concentration, size and amount of certain proteoglycans in the extracellular matrix of the arterial wall, leading to cardiovascular lesions (Radhakrishnamurthy et al. 1989). Additionally, the studies of Hurtig et al. (1993) have shown elevated levels of an active proteoglycan-degrading enzyme (stromelysin) in cartilage lesions in copper-deficient foals. It is surprising therefore that the role of proteoglycan has been completely ignored in studies of the aetiology and pathogenesis of the cartilaginous lesions associated with DOD. Since copper and zinc compounds also have wellestablished pharmacological activity as anti-arthritic agents (Sørenson 1989; Whitehouse et al. 1990) we decided to investigate the effects of these essential metals on the turnover of cartilage matrix proteoglycan. The results of this study should provide insight into their mechanism of action in a variety of degenerative joint diseases.

\section{Materials and methods}

Tissues and culture conditions

Macroscopically normal articular cartilage and synovial tissue were removed from 6 to 9-month-old Landrace pigs and from the lateral trochlear ridge of femorotibial 
joints from 1-year-old horses. Full depth cartilage pieces were cultured alone or were co-cultured immediately adjacent to minced synovial tissue as previously described (Davies et al. 1991).

Cartilage explants and co-cultures were maintained for 48 $\mathrm{h}$ in the presence or absence of $0.01 \mathrm{mM}$ copper sulphate or zinc sulphate. This concentration had previously been shown to be non-toxic as measured by protein and $P G$ synthesis in cartilage and by trypan blue exclusion using isolated chondrocytes (Pasqualicchio et al. 1995, 1996). After $48 \mathrm{~h}$ some of the cartilage explants were removed, snap-frozen in OCT embedding medium and stored at $-20^{\circ} \mathrm{C}$ prior to sectioning for toluidine blue histology and immunocytochemistry. The remaining explants were held in culture for PG synthesis measurements. Five cartilage explants were used in all experimental groups. The experiment was performed 3 times in both species.

\section{Measurement of PG synthesis}

After the $48 \mathrm{~h}$ culture period explants were radio-isotope labelled by replacing the medium with fresh DMEM containing $20 \mu \mathrm{Ci} / \mathrm{ml}(0.74 \mathrm{MBq} / \mathrm{ml})$ of $\left[{ }^{35} \mathrm{~S}\right]$ sulphate and culturing for a further $2 \mathrm{~h}$ at $37^{\circ} \mathrm{C}$. The explants were then placed in tubes previously weighed to determine their wet weight - the explant wet weights were within the range of 50 to $60 \mathrm{mg}$. The explants were then digested in papain $(300 \mu \mathrm{g} / \mathrm{hl})$ for $2 \mathrm{~h}$ at $65^{\circ} \mathrm{C}$ and the rate of $P G$ synthesis measured as the ${ }^{35} \mathrm{SO}_{4}$ incorporation, and expressed as counts per minute/mg (CPM/mg). The experiment was performed 3 times with both pig and horse cartilage and all measurements were done in quintuplicate.

\section{Immunocytochemistry}

Frozen sections of cartilage were cut at a thickness of 5-8 $\mu \mathrm{m}$, air dried for $10 \mathrm{~min}$ and fixed for $30 \mathrm{~min}$ in $4 \%$ paraformaldehyde. Cathepsins $B$ and $D$ were detected by indirect immunolocalization, essentially as described (Davies et al. 1991), using well-characterized sheep antisera raised against human cathepsins $B$ and $D$, known to cross-react with the horse enzymes (Hernandez-Vidal et al. 1996). Controls were performed in which the primary antiserum was replaced with PBS or normal sheep serum. The secondary antiserum was an FITC-conjugated rabbit IgG anti-sheep immunoglobulins (DAKO).

\section{Toluidine blue histology}

Frozen sections were stained with $5 \%(\mathrm{v} / \mathrm{v})$ ethanol containing $0.5 \%(\mathrm{~W} / \mathrm{v})$ toluidine blue for visual assessment of proteoglycan depletion.

\section{Results}

Effects of copper and zinc on cartilage matrix proteoglycan

\section{(i) Effect on PG synthesis}

Incorporation of radioactive sulphate $\left({ }^{35} \mathrm{SO}_{4}\right)$ into newly synthesized proteoglycan was evaluated in explants of pig and horse articular cartilage. Co-culture with synovial tissue dramatically reduced de novo synthesis of PG (Fig. 1)
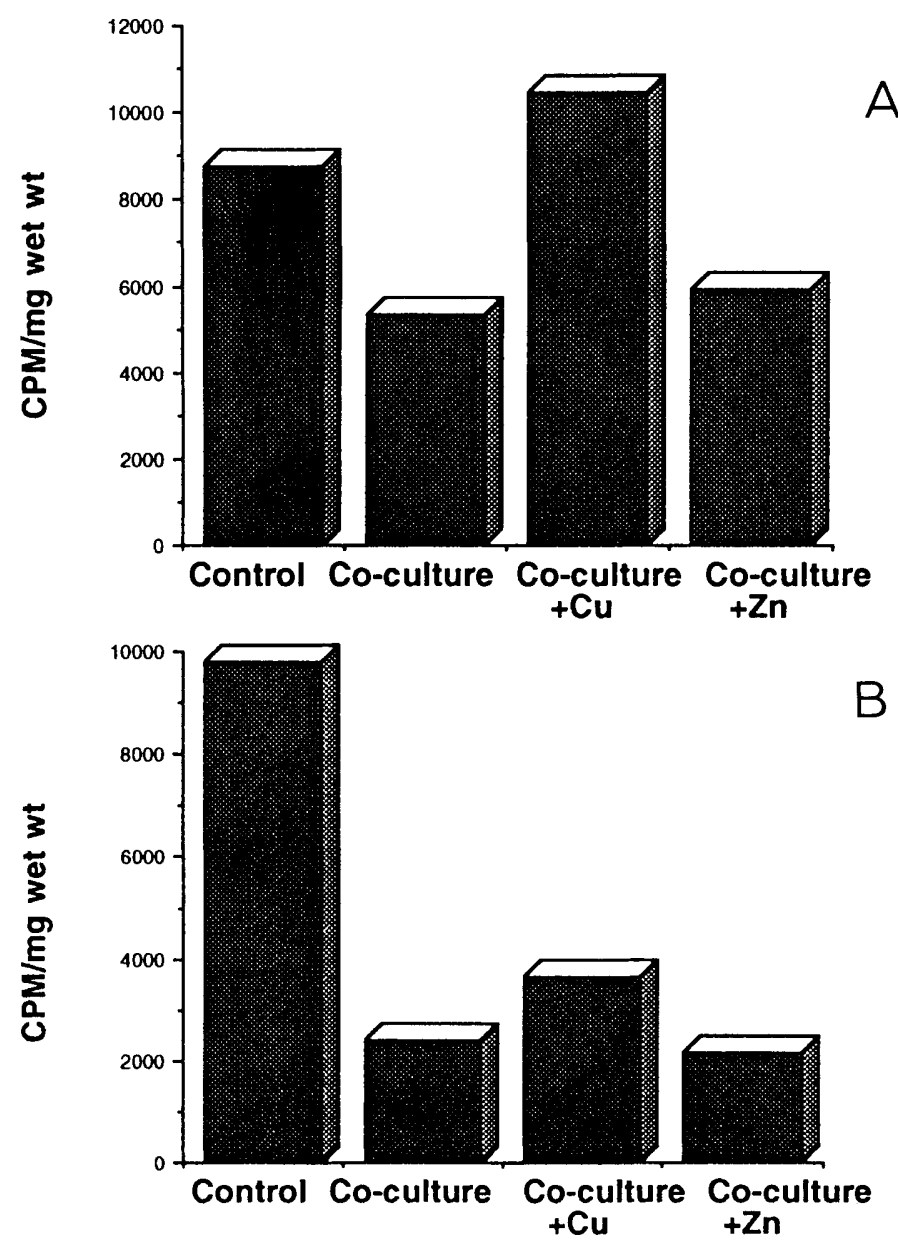

Fig.1: Effect of $0.01 \mathrm{mM}$ copper and zinc sulphate on proteoglycan synthesis (measured as ${ }^{35} \mathrm{SO}_{4}$ incorporation) in normal pig (A) and horse (B) articular cartilage cultured alone (control) or co-cultured with synovial tissue for $48 \mathrm{~h}$.

Wirkung von 0,01 mM Kupfer- und Zinksulfat auf die Proteoglyconsynthese (gemessen als ${ }^{35} \mathrm{SO}_{4}$ Inkorporation) des Gelenkknorpels von Schweinen (A) und Pferden (B) kultiviert allein (Kontrolle) oder co-kultiviert mit Synovialgewebe für $48 \mathrm{~h}$

In all 6 experiments ( 3 pigs, 3 horses) copper sulphate $(0.01 \mathrm{mM})$ caused some degree of reversal of the inhibition of synthesis caused by the synovial tissue. In ccntrast, zinc sulphate (0.01 mM) had no effect. Due to sample and species variation in controls (cartilage alone) ${ }^{35} \mathrm{SO}_{4}$ incorporation, data from different experiments could not be combined. Representative experiments for both pig and horse are presented in Fig. 1A and $B$ respectively.

\section{(ii) Effect on metachromatic staining}

Sulphated proteoglycan levels can be assessed histologically by the deep purple metachromatic stain of toluidine blue. Loss of sulphated PG is associated with a corresponding reduction in the intensity of metachromasia. Normal horse cartilage showed strong metachromatic stai- 


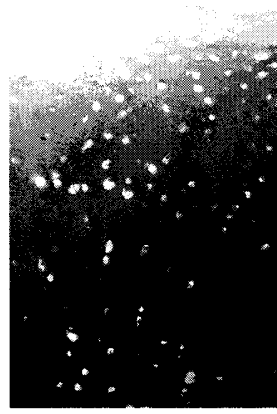

A

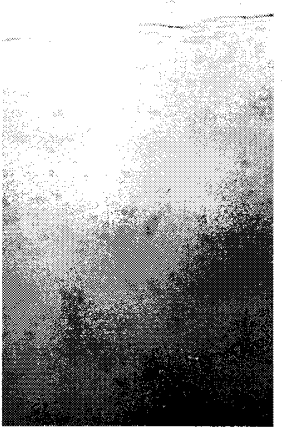

B

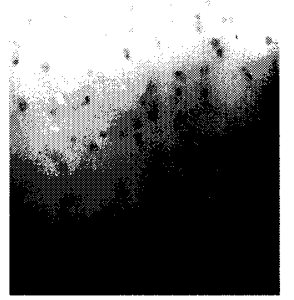

C
Fig. 2: Toluidine blue-stained sections of horse articular cartilage after culture for $48 \mathrm{~h}$ alone (A), co-culture with synovial tissue $(\mathrm{B})$ and co-culture with synovial tissue in the presence of $0.01 \mathrm{mM}$ copper sulphate $(\mathrm{C})$.

Toluidinblau gefärbte Schnitte von Pferdegelenkknorpel nach Kultivierung für 48h: allein (A), mit Synovialgewebe (B) und mit Synovialgewebe und 0,01 mM Kupfersulfat

ning, with slight diminution in intensity at the articular surface after $48 \mathrm{~h}$ in culture (Fig. 2A). In two different experiments co-culture of the cartilage with synovial tissue resulted in extensive depletion of PG as seen by loss of metachromatic staining (Fig. 2B). Copper sulphate at concentrations ranging from $0.001 \mathrm{mM}$ to $1 \mathrm{mM}$ abrogated the PG depletion caused by synovial tissue in a dose-dependent manner. The intensity and distribution of metachromatic staining in Fig. 2C demonstrates the reversal of $P G$ depletion at a copper concentration of $0.01 \mathrm{mM}$. At this concentration of copper distinct "halos" of staining were observed around individual chondrocytes, probably indicating attempts to remodel by „switching on" PG synthesis. Zinc sulphate $(0.01 \mathrm{mM})$ was unable to reverse the PG-depleting effects of synovial tissue (data not shown).

\section{Effect of copper and zinc on expression of cathepsins $B$ and $D$}

The distribution of cathepsins $B$ and $D$ in horse cartilage was assessed by indirect immunolocalization on tissue sections. In a previous study (Hernandez-Vidal et al. 1996) expression of cathepsins $B$ and D was found to be restricted mainly to the hypertrophic chondrocytes with little expression at the articular surface or in the proliferative zone. In the present study, preliminary experiments showed that after co-culture with synovial tissue the majority of chondrocytes stained positively for cathepsins $B$ and $D$ in all zones of the cartilage (Tab. 1). Interestingly, addition of copper sulphate $(0.01 \mathrm{mM})$ considerably reduced the staining reaction of chondrocytes, particularly for cathepsin $D$, at the articular surface and proliferative zone. Zinc sulphate $(0.01 \mathrm{mM})$ had no influence on the staining reaction for either enzyme.

\section{Discussion}

In this study co-cultures of articular cartilage with synovial tissue provided a useful in vitro model to investigate the ef-
Tab.1: Effects of synovial tissue and copper and zinc on the expression of cathepsins $B$ and $D$ in equine articular cartilage.

Wirkung von Synovialgewebe und Kupfer und Zink auf die Expression von Kathepsin B und D in Pferdegelenkknorpel

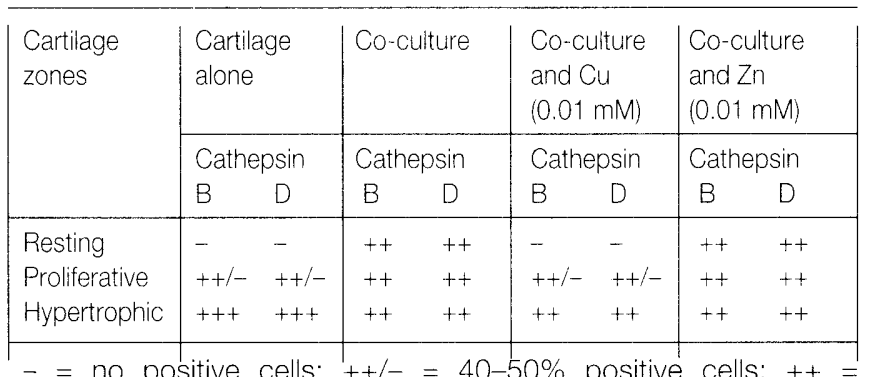

fects of copper and zinc on proteoglycan turnover in the extracellular matrix. Copper, but not zinc, was found to protect the cartilage against the PG-degrading action of synovial tissue, as assessed by (i) measurement of PG synthesis and (ii) by histological staining reactivity. The mechanism by which copper exerts this protective effect is, however, open to speculation.

It is known that normal synovial tissue secretes significant amounts of the pro-inflammatory cytokine interleukin 1(IL_1) (Fell \& Jubb 1977; Davies et al. 1991) and that this cytokine plays a major role in the regulation of cartilage matrix turnover (Lane Smith et al. 1989; Platt \& Bayliss 1994). In vitro studies have shown that IL1 induces cartilage breakdown by stimulating secretion of matrix degrading enzymes by synoviocytes and chondrocytes (Pratta et al. 1989; Nguyen et al. 1989; Malfait et al. 1994), by inhibiting PG synthesis (Tyler 1985; Bayliss et al. 1991) and by altering PG molecular composition (Platt \& Bayliss 1994).

We would like to speculate that copper inhibits IL 1 activity and thereby protects cartilage from synovial-induced damage. Inhibition of IL1 would also explain our observations on the ability of copper to reduce the expression, by chondrocytes, of the PG-degrading enzymes cathepsins B and D. Although we have no experimental evidence in support of this, we do know that copper inhibits nitric oxide (Pasqualicchio et al. unpublished observations), the proposed mediator of IL1-dependent suppression of PG synthesis (Taskiran et al. 1994).

These findings offer a possible explanation for the anti-arthritic action of copper, and may be of significance for the treatment of degenerative diseases such as rheumatoid and osteoarthritis. But is this proposed mechanism of action of copper relevant to the equine DOD? If copper is able to inhibit nitric oxide and/or IL-1, then its ability to influence chondrocyte behaviour must also be considered. Chondrocytes have sole responsibility for maintaining the integrity of their surrounding extracellular matrix which they achieve by controlled secretion of a complex network of mediators and cytokines, including $\mathrm{IL}-1$ and nitric oxide (Rath et al. 1988; Davies et al. 1991; Frean \& Lees 1995). It is clear that any disturbance of this finely balanced microenvioronment e.g. inhibition of nitric oxide or IL-1 by 
copper, could result in production of abnormal or defective cartilage which is characteristic of some of the equine developmental orthopaedic diseases.

\section{References}

Bayliss, M. T., Hickery, M. S. and Hardingham, T. E. (1991): Effects of IL-1 and TNF on human articular cartilage. Differences in biosynthetic and degradative responses Trans. Orthop. Res. Soc. 16, 147-148.

Bridges, C. H. and Harris, E. D. (1988): Experimentally induced cartilaginous fractures (osteochondritis dissecans) in foals fed low-copper diets.J. Am. Vet. Med. Assoc. 193, 215-221

Bridges, C. H. and Moffitt, P. G. (1990): Influence of variable content of dietary zinc on copper metabolism of weanling foals. Am. J. Vet. Res. 51, 275-280

Bridges, C. H., Womack, J. E. and Harris, E. D. (1984): Considerations of copper metabolism in osteochondrosis of suckling foals. J. Am. Vet. Med. Assoc. 185, 173-178

Cymbaluk, N. F. and Smart, M. E. (1993): A review of possible metabolic relationships of copper to equine bone disease. Equine Vet. J. Suppl. 16, 19-26

Davies, M. E., Horner, A. and Dingle, J. T. (1991): Immunorecognition of chondrocytes in articular cartilage activated by synovial interleukin 1. Conn. Tiss. Res. 25, 243-249

Fell, H. B. and Jubb, R. W. (1977): The effect of synovial tissue on the breakdown of articular cartilage in organ culture. Arth. Rheum. 20, 1359-1371

Frean, S. and Lees, P. (1995): Equine chrondrocytes, but not synoviocytes, produce nitric oxide in response to lipopolysaccharide. Inflamm. Res. 44, Suppl. 3, S 235.

Hernandez-Vidal, G. M., Davies, M. E. and Jefcott, L. B. (1996): Localisation of cathepsin $B$ and $D$ in equine articular cartilage. Pferdeheilkd. 12, 371-373

Hurtig, M. B., Green, S. L., Dobson, H. et al. (1993): Correlative study of defective cartilage and bone growth in foals fed a low-copper diet. Equine Vet. J. Suppl. 16, 66-73

Knight, D. A., Weisbrode, S. E., Schmall, L.M. et al. (1990): The effects of copper supplementation on the prevalence of cartilage lesions in foals. Equine Vet. J. 22, 426-432

Lane Smith, R., Allison, A. C. and Schuman, D. J. (1989): Induction of articular cartilage degradation by recombinant interleukin $1 \alpha$ and $1 \beta$.

Malfait, A. M, Verbruggen, G., Almqvist, K. F. et al. (1994): Coculture of human articular chondrocytes with peripheral blood mononuclear cells as a model to study cytokine-mediated interactions between inflammatory cells and target cells in the rheumatoid joint. In Vitro Cell. Dev. Biol. 30, 747-752

Meyer, H. (1994): Kupferstoffwechsel und Kupferbedarf beim Pferd. Übers. Tierernähr. 22, 363-394

Nguyen, Q., Murphy, G. M., Roughley, P. J. et al. (1989): Proteoglycan aggregate degradation by a cartilage metalloproteinase. Evidence for the involvement of stromelysin in the generation of link protein heterogeneity in situ. Biochem. J. 259, 61-67
Pasqualicchio, M., Davies, M. E. and Velo, G. P. (1995): Effects of copper and zinc on chondrocyte-mononuclear cell adhesion via ICAM-1/CD18 interactions. Inflammopharmacol. 3, 35-48

Pasqualicchio, M., Gasperini, R., Velo, G. P. et al. (1996): Effects of copper and zinc on proteoglycan metabolism in articular cartilage. Med. of Inflamm. 5, (in Press)

Platt, D. and Bayliss, M. T. (1994): An investigation of the proteoglycan metabolism of mature equine articular cartilage and its regulation by interleukin-1. Equine Vet. J. 26, 297-303

Pratta, M. A., Dimeo, T. M., Ruhl, D. M. et al. (1989): Effect of interleukin $1 \beta$ and tumour necrosis factor- $\alpha$ on cartilage proteoglycan metabolism in vitro. Agents Actions 27, 250-253

Radhakrishnamurthy, B., Ruiz, H., Daleferes, E. R. et al. (1989): Composition of proteoglycans in the aortas of copper-deficient rats. Proc. Soc. Exp. Biol. Med. 190, 98-104.

Rath, N.C., Oronsky, A.L. and Kerwar, S. S. (1988): Synthesis of interleukin-1-like activity by normal rat chondrocytes in culture. Clin. Immunol. Immunopathol. 47, 39-46.

Sorenson, J. R. J. (1989): Copper complexes offer a physiological approach to treatment of chronic diseases. In Progress in Medicinal Chemistry, Vol. 26 (ed Ellis, G. P. \& West, G. B.), pp. 437-568. Amsterdam: Elsevier.

Taskiran, D., Stefanovic-Racic, M., Georgescu, H. et al. (1994): Nitric oxide mediates suppression of cartilage proteoglycan synthesis by 1L-1. Biochem. Biophys. Res. Comm. 200, 142-148

Tyler, J. A. (1985): Articular cartilage culture with catabolin (pig interleukin 1) synthesizes a decreased number of normal proteoglycan molecules. Biochem. J. 227, 869-878

Whitehouse, M. W., Rainsford, K. D., Taylor, R. M. et al. (1990): Zinc monoglycerate: a slow release source of zinc anti-arthritic activity in rats. Agents Actions 31, 47-58

M. E. Davies wishes to thank the Wellcome trust for financial support

M. E. Davies

G. Hernandez-Vidal

Strangeways Research Laboratory

Worts Causeway

Cambridge CB1 $4 R N$

UK

\section{Pasqualicchio}

Istituto di Farmacologia

Universita di Verona

Policlinico Borgo Roma

37134 Verona

Italy

\section{F. Henson}

University of Cambridge

Department of Clinical Veterinary Medicine

Madingley Road

Cambridge CB3 OES

UK 